\title{
O corpo como resistência paratópica do discurso da negritude no discurso literário
}

Rosângela Aparecida Ribeiro CARREIRA

\section{Considerações iniciais}

O discurso, explícita ou implicitamente, quase sempre estabelece ou demonstra relações de poder e resistência estabelecidas no tempo e no espaço, conforme estudos de Althusser (1998), Pêcheux (1975), Foucault (2004-2005a) e Maingueneau (1983-2015), estudos que servem de suporte para o desenvolvimento deste capítulo para fundamentar a noção de paratopia do discurso da negritude.

Tais princípios serviram de norte para análise de "Vencidos e Degenerados" de José Nascimento Moraes, romance maranhense publicado em 1910, cuja materialidade discursiva reitera essas rela- 
ções. Nosso primeiro movimento analítico teve por objetivo revelar que as condições sócio-históricas de produção delineiam uma proxêmica discursiva capaz de desvendar elementos que levaram à concepção de uma paratopia documento-testemunhal do discurso da negritude, como ampliação das noções dadas por Maingueneau (1996, 2006 e 2010).

Consideramos discurso da negritude aquele que é instaurado pelas redes semânticas globais simbólicas estabelecidas como reação, defesa e manifesto do perfil cultural do negro, seja de forma tópica, atópica ou paratópica, em diferentes gêneros do discurso e por diferentes formações discursivas. A partir do corpus e dos resultados obtidos em nossa tese de doutorado, procedemos à ampliação das discussões lá estabelecidas por meio do questionamento: como elementos como capoeira, beleza e embriaguez denotam uma característica paratópica no discurso literário que reiteram a resistência negra com e pelo corpo?

Para este capítulo, buscamos um novo percurso, cujo objetivo principal é verificar se a categoria paratopia pode ser aplicada ao corpo como interactante do processo discursivo. Para isso, analisamos a cena de enunciação que envolve os enunciadores Aranha, Andreza e Zé Catraia, sobretudo, no que concerne ao corpo como elemento caracterizador de uma determinada cultura e de eixo estruturante de uma resistência política nesse discurso literário.

Utilizamos a característica interdisciplinar da AD apropriando-nos dos conceitos dados ao termo negritude por Cesàrie (1987), Fanon (2008) e Munanga (2006 e 2012), somados aos conceitos de proxêmica estabelecidos por Hall (1977), Knap (1982) e autores da Antropologia, Sociologia e História. 


\section{Historicidade e identidade: a negritude conceitua- $d a$}

O termo negritude deve ser entendido pela inter-relação do discurso com os níveis político, ideológico, filosófico e cultural, em suas múltiplas acepções, pois, consoante Munanga (2012), o termo, no decorrer da História, assume uma variedade de definições de caráter biológico, ou racial, conceitual, psicológico e cultural. Antes de falarmos desses diferentes fatores que fazem parte da negritude, é relevante ressaltar que o termo está intimamente relacionado à identidade e ao que ela significa como particularização de um indivíduo ou de um grupo.

A negritude nasce de um sentimento de frustração dos intelectuais negros por não terem encontrado no humanismo ocidental todas as dimensões de sua personalidade. Nesse sentido, é uma reação, uma defesa do perfil cultural do negro. Representa um protesto contra a atitude do europeu em querer ignorar outra realidade que não a dele, uma recusa da assimilação colonial, uma rejeição política, um conjunto de valores do mundo negro, que devem ser reencontrados, defendidos e mesmo repensados. Resumindo, trata-se primeiro de proclamar a originalidade da organização sociocultural dos negros, para depois defender sua unidade através de uma politica de contra-aculturação, ou seja, desalienação autêntica (MUNANGA, 2012, p. 63, grifo nosso).

Somando essa perspectiva ao território de embates a que pertence o discurso, consideramos discurso da negritude aquele que 
é instaurado pelas redes semânticas globais estabelecidas como reação, defesa e manifesto do perfil cultural do negro, seja de forma tópica, atópica ou paratópica, em diferentes gêneros do discurso e em diferentes FDs.

Com relação à identidade, se o Brasil e o povo negro passaram por uma (des)construção identitária e lutaram e lutam por sua (re) construção, vivemos um momento precoce de conceituação dessa identidade, mas, ainda assim, somos levados a nos perguntar: até mesmo essa busca não seria uma imposição, uma idealização, uma nova representação ou uma invenção discursiva?

Não há uma resposta pontual, ou factual, para essa questão, porque a construção da identidade é simbólica e social. Simbólica porque apresenta característica relacional de sistemas que a representem, como, por exemplo, após a Lei do Ventre Livre, quando a identidade do negro nascido livre se diferenciava do grupo de escravos, mas, ainda assim, a característica étnica mantinha uma característica relacional, de sorte que é preciso associar diferentes elementos sociais para criar características que gerem uma identidade. Social porque é a exclusão, ou a inclusão num grupo social, ou em características de dado momento histórico, que permitirá identificar diferenças ou semelhanças que unam um grupo em torno de dada identidade. Para Woodward (2012, p. 11),

a identidade é marcada pela diferença, mas parece que algumas diferenças - neste caso entre grupos étnicos são vistas como mais importantes que outras, especialmente em lugares particulares e em momentos particulares. 
Essa particularização leva a outras características inerentes à identidade, como a noção de pertencimento: pertencer ou não, partilhar ou não o espaço com alguém ou o espaço de alguém, há um movimento relacional entre um nós囚eles. São as representações simbólicas estabelecidas nessa relação, ou no hiato que subjaz a elas, que criam novos sentidos para as desigualdades sociais, exclusões, divisões e estigmas.

Apesar dessa relação, importante é realçar a ideia de fluidez estabelecida por Hall (1997); ou seja, ainda que haja um "eu” e o "outro", um "nós" e "eles", por serem movidos pela existencialidade e sociedade, novos movimentos sociais e novas características podem surgir a qualquer momento, como, por exemplo, o movimento feminista, o neofeminismo e o feminismo negro, movimentos que partilham da mesma raiz, porém apresentam ordenações identitárias distintas.

Seria como afirmar que o cerne das diferenças que compõem a identidade está em opostos que se atraem e, contraditoriamente, se assemelham sob alguns aspectos. A identidade associa-se à diferença de forma flexível, móvel e circular. Ou seja, ainda que haja a relação nós>eles, eu>eles, uns>outros, não se trata de mera relação binária, por que, além dos fatores externos, competem também fatores internos, em que as subjetividades entram em ação. Aqui, entram em xeque a "subjetividade", a "identidade" e o "ethos". Embora "subjetividade" e "identidade" sejam termos tomados como sinônimos, quase sempre, e de forma inadequada, são conceitos distintos:

"Subjetividade" sugere a compreensão que temos sobre nosso eu. O termo envolve os pensamentos e as emoções conscientes e inconscientes que constituem nossas concepções sobre "quem nós somos". A subjetividade envolve sentimentos e pensamentos pessoais. Entretanto, nós 
vivemos nossa subjetividade em um contexto social no qual a linguagem e a cultura dão significados à experiência que temos de nós mesmos e no qual nós adotamos uma identidade. Quaisquer que sejam os conjuntos de significados construídos pelos discursos, eles só podem ser eficazes se eles nos recrutam como sujeitos. Os sujeitos são, assim, sujeitados ao discurso e devem, eles próprios, assumi-lo como indivíduos que, dessa forma, se posicionam a si próprios. As posições que assumimose com as quais nos identificamos constituem nossas identidades (WOODWARD, 2012, p. 56).

O ethos, por sua vez, é uma imagem de si (de um sujeito) projetada no/pelo discurso, a qual pode, ou não, aproximar-se da subjetividade e/ou da identidade de um enunciador ou de um grupo. Isto é, o ethos pode servir como elemento identitário de grupo, como ética; ou pode ser a projeção de um sujeito; ou mera criação para propiciar a adesão. Considerando que sujeito, a partir da concepção de Althusser (1998), não é semelhante à pessoa humana, mas categoria simbolicamente construída nas relações de poder instituídas no aparelho formal do Estado, e a subjetividade pode ser explicada por meio de práticas sociais e simbólicas, nas quais as ideologias são sistemas de representação que recrutam sujeitos entre os indivíduos, ou transformam indivíduos em sujeitos.

Portanto, enquanto o ethos é uma criação do enunciador, a subjetividade está em suas ações e práticas sociais, no processo interativo, enquanto a identidade está ligada à ideologia e às posições assumidas por um sujeito dentro da sociedade. Diríamos que o ethos e a subjetividade são endofóricos; emergem de dentro para fora nos/dos discursos, enquanto a identidade é um movimento de fora para dentro do discurso, ou de uma FD. 
Do mesmo modo, entendemos o discurso da negritude como categoria simbólica que demonstra a reação de um enunciador negro ou que toma a voz do povo negro para mobilizar-se de forma reacionária.

Fanon (2008) evoca esse discurso da negritude de forma inusitada, e dessa inter-relação eu-outro emerge o racismo; um grupo de pessoas sai dessa relação e em nome dela se sente no direito de insurgir violentamente contra o outro. Sem perceber, a luta contra o racismo encontra-se não em ser o outro, mas em se inserir nessa relação, ou seja, a luta está em ser aceito pelo outro, mas o contrassenso racional é de que o negro não precisa e não deve ser aceito pelo outro porque, simplesmente, sua existência independe do outro.

O autor aborda uma consciência do existir que deve negar o branqueamento e defende que o apagamento imposto pelo branco desintegra a imagem de si mesmo, a imagem do negro e do colonizador, pois, para compreender e mudar a situação do negro é preciso que essa imagem social "deixe de existir" para se ressignificar e não ser colocado na situação de inferior, reaproximando distâncias, pois

enquanto o negro estiver em casa não precisará, salvo por ocasião de pequenas lutas intestinas, confirmar seu ser diante de um outro. Claro, bem que existe o momento de "ser para-o-outro", de que fala Hegel, mas qualquer ontologia torna-se irrealizável em uma sociedade colonizada e civilizada. Parece que este fato não reteve suficientemente a atenção daqueles que escreveram sobre a questão colonial (FANON, 2008, p. 104). 
"Ser para-o-outro" significa deixar de ser, pois não é possível realizar seu ser diante do outro, ou ser para o outro, se, para este "outro", o "ser" não existe, foi "objetificado". Transformados em objetos, os grupos étnicos escravizados perderam-se de si, daí essa ressignificação de sua identidade, não para o outro, mas para si mesmos (o Ser) e para o grupo ao qual pertencem como resistência e reafirmação social.

Nessa situação, os sujeitos encontram-se no que Bhabha (1998) denominou de "entre-lugar". Para ele,

o afastamento das singularidades de "classe" ou "gênero" como categorias conceituais e organizacionais básicas resultou em uma consciência das posições de sujeito - raça, gênero, geração, local institucional, localidade geopolítica, orientação sexual - que habitam qualquer pretensão à identidade no mundo moderno. O que é teoricamente inovador e politicamente crucial é a necessidade de passar além das narrativas de subjetividades originárias e iniciais e de focalizar aqueles momentos ou processos que são produzidos na articulação de diferenças culturais. Esses "entre-lugares" fornecem o terreno para a elaboração de estratégias de subjetivação - singular ou coletiva - que dão início a novos signos de identidade e postos inovadores de colaboração e contestação, no ato de definir a própria ideia de sociedade (BHABHA, 1998, p. 20-1).

Esses entre-lugares estabelecidos em estratégias de subjetivação consolidam-se no discurso, atravessam suas fronteiras, representadas em tópicas, atópicas e paratópicas múltiplas focadas como 
resistência às nulidades impostas na cena que enuncia a renovação da própria enunciação. É na linguagem e pela linguagem que os sujeitos buscam validação social, imposição e renovação dos "dizeres" que o deslocam e provocam assimilações e apagamentos impostos por um discurso que se apoia na "tradição".

Se pensarmos na arqueologia do discurso de Foucault (2005a) no que concerne aos discursos constituintes como elementos fundadores de um "dizer", assumimos que os discursos constituintes que compõem o universo das civilizações negras no Brasil e das demais regiões estão longe de ser alcançados pela população branca, pois não é possível ainda chegar à origem fundadora.

Se, por um lado, temos um mundo globalizado, Movimentos Negros mais estruturados, igualdades garantidas por lei, mais democracias e liberdade de imprensa, e, por outro, ainda temos civilizações racistas, desconhecimentos e desrespeitos com a diáspora e a cultura africanas, permitimo-nos dizer que há, entre ambas as civilizações, uma espécie de paradoxo de Fermi social ${ }^{22}$. Existe, por parte do branco, resistência em reconhecer o negro como igual e como alteridade.

Essa igualdade inexiste, na verdade, porque nem existe o branco, nem existe o negro, logo, não há diferenças ou igualdades, e o

22 Enrico Fermi, Prêmio Nobel de Física em 1938, foi um físico italiano que desenvolveu o primeiro reator nuclear e esteve envolvido em projetos científicos sobre a utilização da energia nuclear durante a Segunda Guerra Mundial e, durante o pós-guerra, com Michael H. Hart. Em 1975, institui-se o paradoxo de Fermi que surge do questionamento relacionado à idade do universo e à existência de outras civilizações, os físicos questionam por quê não há evidências de existências de outras civilizações extraterrestres, sondas ou indícios de vida, sendo o universo milenar e creem que há barreiras que impedem esse acesso, mas também há o princípio da mediocridade, que faz com que os terrestres julguem-se únicos e neguem a existência de outras populações. Disponível em: <http://www.nobelprize.org/nobel_prizes/physics/laureates/1938/fermi-bio. html>. Acesso em: 5 jan. 2015. 
que competiria à raça humana, competiria aos movimentos políticos e culturais de origem negra. De certo modo, o princípio da mediocridade que faz parte do paradoxo de Fermi também se aplica à relação civilizações brancas versus civilizações negras, pois as civilizações dominadoras e escravocratas, num primeiro momento, negaram qualquer cultura, conhecimento ou herança proveniente da África, mas as aculturaram, as escravizaram e as dizimaram. Negaram também a existência dessa civilização e dessas ações.

Da abolição até a atualidade, brancos se apropriam e apreciam cada vez mais a cultura, o folclore e os conhecimentos do negro, mas, ainda assim, negam, não valorizam, ou não assimilam a existência de uma cultura negra sem a intervenção dos colonizadores. E esse é o grande paradoxo: o princípio da mediocridade impera.

No cotidiano, o negro vai enfrentar o seu inverso, forjado e imposto. Ele não permanecerá indiferente. Por pressão psicológica, acaba reconhecendo-se num arremedo detestado, porém convertido em sinal familiar. A acusação perturba-o, tanto mais porque admira e teme seu poderoso acusador. Perguntar-se-á, afinal, se o colonizador não tem um pouco de razão. Será que não somos mesmo ociosos ou medrosos, deixando-nos dominar e oprimir por uma minoria estrangeira? A tecnologia superdesenvolvida trazida pelo branco ajudaria a instaurar uma situação de crise na consciência do negro. Nesse sentido, em algumas culturas, o branco foi comparado a Deus e aos ancestrais (MUNANGA, 2012, p. 37).

$\mathrm{Na}$ busca de romper com a mediocridade e com o paradoxo que afirmamos existir, o negro se vê com o olhar do outro e, his- 
toricamente, sobretudo a elite negra, busca assemelhar-se ao outro, embranquecer-se, assimila valores culturais, como primeira tentativa de reclamar direitos sociais. No enunciado de Vencidos e Degenerados, observa-se que, na sociedade, já havia ex-escravos que juntavam dinheiro para ter seus escravos (retomaremos esse aspecto durante a análise), (re)inventando seu lugar social e criando o "entre-lugar" dito por Bhabha (1998). A segunda tentativa, possivelmente a mais leal, é a de negação desse branqueamento e de retorno às origens.

Mesmo com a recusa da assimilação, as três primeiras gerações de colonizados não almejavam a coletividade ou busca de uma identidade negra. Segundo Munanga (2012), sua aspiração principal era obter um nível de vida semelhante ao do branco.

A negritude surge efetivamente quando esse confronto e essa contestação saem do individual e passam ao coletivo, como negação da supremacia colonizadora e, sobretudo, quando envolve o povo colonizado. Condicionada pela evolução político-econômica, dentro e fora do País, evolui, então, para o atual pan-africanismo, que apregoa o retorno às origens para reafirmar e lutar pela identidade do negro africano dentro e fora da África, pois

o vento que as levou soprou a partir das Américas, tendo como origem provável os Estados Unidos, passando pelo Haiti, seguindo seu caminho até a Europa, manifestando-se na Inglaterra para se cristalizar, enfim, na França, em Paris, no Quartier Latin. A partir daí, alastra-se cobrindo toda a África negra e os negros em diásporas, isto é, as Américas (MUNANGA, 2012, p. 45).

Nos Estados Unidos, intelectuais e escritores negros unem-se para romper com o complexo de rejeição e exclusão social; desta- 
cam-se entre eles Longston Hughes ${ }^{23}$, Pai da Negritude e W. E. B. Du Bois ${ }^{24}$, autor de Almas Negras. Na Europa, o Renascimento Negro é aflorado ao final da Segunda Guerra Mundial, principalmente na França, onde a movimentação começou acirrada no Quartier Latin $^{25}$. Destacam-se, entre outros, Dr. Prince-Mars ${ }^{26}$, René Ma$\operatorname{ran}^{27}$, o senegalês Leopold Sedar Senghor ${ }^{28}$, o guianense Leon Damas $^{29}$, e Aimé Césarie ${ }^{30}$, martiniquense e criador da ideologia da negritude para aquele contexto (MUNANGA, 2012).

23 Poeta norte-americano politicamente ativo no movimento de valorização da cultura afro no Harlem, em 1920.

24 Sociólogo, historiador e ativista no Movimento Pan-africano nos EUA.

25 O Quartier Latin é o complexo universitário e intelectual que se situa no coração de Paris. Dali parte a maioria dos movimentos políticos e as transformações sociais da contemporaneidade, embora já fosse influente durante a Idade Média. Os roteiros turísticos o designam como região formada pelos bairros 5 e 6 de Paris.

26 Jean Prince-Mars nasceu em Grande Rivière du Nord (Haiti), em 15 de outubro de 1876, e morreu em Petionville (Haiti), em 1o de março de 1969. Era médico, etnógrafo, diplomata, estadista, educador e escritor, e considerado como o principal mentor do Haiti no século XX e ativista nos movimentos negros.

27 René Maran, escritor e ensaísta da Martinica, conhecido por despertar na sociedade negra a consciência de seu poder e sua força nos movimentos negros. Seu romance mais famoso é Batouala, o Verdadeiro Romance Negro, com o qual ganhou o prêmio Prix Councourt.

28 Político e escritor senegalês que idealiza, com Aimé Cesare, o conceito de negritude, durante o período que se estende do início da Primeira Guerra ao final da Segunda Guerra Mundial. É possível ter noção de sua atuação política. Kabengelê utiliza o texto Ames Moires, escrito por este autor e publicado em 1977 em obra organizada pela Universidade Católica de Louvain.

29 Léon-Gontran Damas foi um escritor, poeta e político francês, nascido a 28 de março de 1912 na Guiana Francesa e falecido a 22 de janeiro de 1978 nos Estados Unidos. Era mestiço de negro, ameríndio e branco. Sobre ele, há uma obra intitulada The Negritude reviseted - A interview by Léon Damas.

30 Foi fundador da Negritude juntamente com Sengor e Damas, nasceu na Martinica e foi ideólogo do conceito de negritude e defensor dos direitos africanos. 
Sartre (1968) considera que esse movimento de nascimento e reação da cultura negra e negação da cultura branca é um antirracismo necessário, em que o sujeito segue um processo em que morre a cultura branca para renascer a cultura negra. Esse movimento de reação política, social e cultural feito por meio das artes em geral e a partir do qual emana a voz significativa do negro, é o que chamaremos de discurso da negritude. É o discurso que rompe com as relações de poder instauradas e leva o filósofo a se questionar sobre a utilização política da língua francesa e as relações socioculturais.

Conforme salienta Arantes (2011, p. 393), “a palavra nègre será invertida, para reivindicar a busca de raízes africanas e a construção de uma nova identidade”. Essa reivindicação fortalecerá e questionará o próprio termo negritude, o qual assume valores polissêmicos. Bernd (1988), com enfoque mais literário, faz leitura aproximada das questões trazidas por Munanga (2012) e defende que o termo pode apresentar muitos significados, como: fazer parte desse grupo étnico; a própria raça tomada individualmente; a ação consciente e reivindicatória do homem negro civilizado; o estilo artístico ou literário desse grupo de artistas; e, ainda, o conjunto de valores da civilização africana.

Para este trabalho, assumimos os estudos de Munanga (2012) como princípio norteador da participação do negro nos Movimentos Negros e nas diferentes acepções de negritude, a qual se resume em: identidade, fidelidade e solidariedade. (CÉSARIE apud MUNANGA, 2012).

Os principais objetivos dos movimentos que envolvem a negritude são: a busca de uma identidade cultural negra africana; luta pela emancipação dos povos subjugados; uma civilização universal dialógica; e repúdio ao ódio (MUNANGA, 2012). Ou seja, a ne- 
gritude envolve objetivos, ações de cunhos pessoal e coletivo, procedimentos e estratégias, resgate, partilha e transformação. Posto isso, não fica difícil verificar a complexidade e a magnitude desse movimento como tentativa de ruptura do paradoxo (Fig. 1).

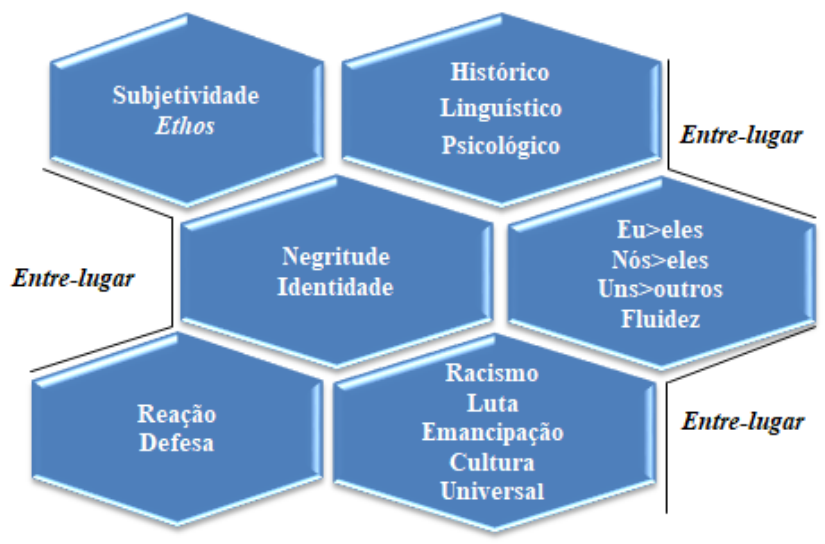

Figura 1. Negritude e identidade

Adaptado de Munanga (2012), Bhabha (1998) e Fanon (2008)

Em razão do "Renascimento Negro" e do complexo sistema entremeado por entre-lugares, há muitas interpretações para o termo negritude. Munanga (2012) parte dos estudos de Lecherbonnier (1977) e Bimwenyi-kweshi (1977) e reitera que há pelo menos duas acepções antinômicas: uma mítica e outra ideológica. Enquanto a primeira busca as origens primitivas anteriores à colonização, a segunda impõe um modo de ação, ao negro, uma negritude ofensiva em resposta às degradações do passado. Entre essas duas, há uma gama de definições que preveem aspectos relacionados à identidade dos movimentos. 


\begin{tabular}{|c|c|}
\hline Definições & Características \\
\hline De caráter biológico ou racial & $\begin{array}{l}\text { - Associada à solidariedade cesariana, } \\
\text { são todos os aspectos que unem a raça } \\
\text { negra e a noção de pertencimento. }\end{array}$ \\
\hline De base sociocultural ou classe & $\begin{array}{l}\text { - Reduz raça a classe. Visão classista } \\
\text { mascara os mecanismos de opressão. }\end{array}$ \\
\hline De caráter psicológico & $\begin{array}{l}\text { - Conjunto de traços psicológicos } \\
\text { característicos: comportamento, ca- } \\
\text { pacidade de emoção, personalidade e } \\
\text { alma. }\end{array}$ \\
\hline De caráter cultural e ambíguo & $\begin{array}{l}\text { - Negritude-essência versus tomada } \\
\text { de posição; } \\
\text { - Negritude mistificada (sonhadora; } \\
\text { contemplativa)/válida(combativa); } \\
\text { - Negritude eterna/episódica e histó- } \\
\text { rica; } \\
\text { - Negritude ególatra e autossuficiente } \\
\text { versus acabada no passado; } \\
\text { - Negritude voltada ao passado versus } \\
\text { projetada ao futuro; } \\
\text { - Ideológica versus utópica; } \\
\text { - Real versus mítica. }\end{array}$ \\
\hline $\begin{array}{l}\text { Outras ordens a partir da literatura } \\
\text { sobre o tema }\end{array}$ & $\begin{array}{l}\text { - Dolorosa; } \\
\text { - Agressiva; } \\
\text { - Serena; } \\
\text { - Vitoriosa. }\end{array}$ \\
\hline
\end{tabular}

Quadro I - Definições de negritude relacionadas à identidade dos movimentos Adaptado de Munanga (2012)

Até aqui fizemos um percurso teórico para a análise das condições sócio-históricas de produção em que surge o termo negritude, a partir dos movimentos políticos e culturais conhecidos como Renascimento Negro. Contudo, em nosso entender, em todos os momentos houve algum tipo de reação e/ou manifestação, embora não registrada historicamente, ou seja, mesmo antes de a negritude firmar-se politicamente, o discurso da negritude já existia. 
Durante o período colonial, por exemplo, o gênero carta de alforria pertence à FD escravocrata e é elemento que denota a relação de poder entre dominador/dominado. Sua posse era privilégio social de uma minoria que passava por trabalhos e sofrimentos impensáveis para obtê-la; quando utilizada para recolocação no mercado de trabalho livre, a carta tornava-se carta de apresentação, documento de identificação e imprimia, dessa maneira, novo significado às relações entre os enunciadores. São das análises dessas relações interativas que se observam as de poderio, daí, emanam espaços e universos discursivos.

No caso específico da relação discursiva entre civilizações, o paradoxo se estabelece justamente porque o discurso da negritude surge como ação social. Com ela, surgem discursos que atravessam essas barreiras e fazem com que a civilização branca a aceite, seja por razões de fato e direito, seja por imposições sociais. De forma aberta ou velada, entretanto, os embates continuam e não há uma aceitação completa por parte de ambos, sobretudo, por parte dos brancos que negam a cultura das civilizações negras e resistem em considerar suas religiões e organizações sociais. Negam até a constituência de um discurso independente.

Se, por um lado, brancos aceitam as danças, vestimentas, idealizam safaris, canções e lendas, por outro, negam cultos religiosos islâmicos em algumas regiões, negam cultos de candomblé e, inclusive, muitas vezes, não associam a ideia de intelectualidade à África. É diante desses embates que surge o discurso da negritude. Portanto, temos múltiplos universos interseccionados, paralelos e marginais. 


\section{Discurso da Negritude e os ethé do negro na socie- dade maranhense}

O enunciador central da sociedade maranhense e da cena genérica proposta em Vencidos e Degenerados é o negro, incorporado na imagem de "morenos, mulatos, mulatas, crioulos e pretos retintos" e demais adjetivos como são identificados durante a interlocução na cena de enunciação.

Do cenário apresentado na primeira etapa que vai da expectativa da abolição, passa pela Lei Áurea, pela queda do regime monárquico, até chegar à República decadente, à morte de Olivier e ao início da segunda etapa com Cláudio. O discurso do dominador segue de forma ora velada, ora explícita e dominados ou se adaptam ou são excluídos.

Do universo discursivo político, apreendemos campos discursivos relativos à escravidão, à abolição e à República, cujos espaços discursivos relacionados à inserção do negro nessa nova formação social são representados por diferentes sujeitos e vozes que constroem a trama e, consequentemente, a rede semântica.

Os campos discursivos são atravessados pelo discurso do capital, do mercado, do trabalho, da inclusão/exclusão, da violência, do racismo e da negritude, conforme começamos a demonstrar acima. Nosso foco, porém, está no discurso da negritude, embora não desconsidere(mos) a existência dos demais, porque o consideramos um discurso de resistência e consciência negra atemporal. Logo, é preciso estar ciente da existência dos demais discursos para reagir.

A violência de fato imposta à população negra escravizada torna-se responsável pelo "estado de violência" que surge durante o processo de escravidão, durante o período pré-abolição e se 
mantém pós - abolição. A enunciação reifica essa violência em [1], [2] e [3] e converte o dito relatado numa possibilidade de registro histórico daquilo que foi deixado de lado pela História nacional e é contra isso que surge o discurso da negritude.

1. Lousada era um terrível senhor de escravos, que abalava a cidade com suas torpezas, quase diariamente cometidas, com variantes de requintada selvageria. (p. 30)

2. Lousada tinha especiais e originalíssimos instrumentos de suplício, tais como: cabos preparados com estilhaços de vidros, por onde forçosamente subiam e desciam os escravos, até cortarem inteira e profundamente as mãos: redes com lâminas lacerantes e pregos onde se embalavam, num horrível balanço, aqueles infelizes, até se retalharem as carnes e se rasgarem os tecidos das costas e dos flancos; martelinhos para baterem na arcada do peito até o sangue espirrar ou golfar pelo nariz e pela boca; espetos de ferro que se levavam ao fogo até o rubro, para queimarem os olhos, a língua e os membros dos escravos, que endoideciam nas prisões úmidas e sufocantes do pavimento térreo. (p. 30-1)

3. De noite, à placidez mórbida e pavorosa de seu silêncio ouviram, os que moravam nas casa contíguas ao sobrado do coronel Lousada, gemidos surdos que mãos de ferro violentamente estrangulavam na garganta, espanqueamento de corpos, de encontro às paredes e às lajes, queixas e ais (...) (p. 31)

4. Diziam os que a conheciam que era uma mulher má, sedenta de cruéis castigos, e que se apontava, distinta, pela impiedade de sua cólera, pelo arrebatamento do gênio irascível e impensadas ações. (p. 36)

Era uma cafuza ainda nova, farta de carne, sensual, de bem talhadas formas sedutoras, que fascinara o marido da senhora, um velho comendador, bonacheirão, roído de reumatismo, constrangido de achaques próprios da velhice, mas que ainda tinha vista para os atrativos do gozo. (p. 36)

Quadro II - A violência

Fonte: Vencidos e Degenerados (MORAES, 2000)

É contra essa imagem "objetificada" que, na estratificação social, surgem embates entre os diferentes enunciadores. Ao contrário do que reza o senso comum, não há passividade na escravidão, os sujeitos não a acataram e a aceitaram. Imposição não é aceitação, e silêncio não significa necessariamente passividade, embora os registros históricos oficiais, por muito tempo, tenham omitido a verdadeira história e tenham criado um discurso idealizado do 
processo escravocrata sob uma perspectiva eurocentrista.

Se, por um lado, a escravidão trouxe um apagamento dos sujeitos, por outro, é importante ressaltar que a força negra também se manifestou socialmente, não no sentido físico, mas na composição de uma imagem de liderança, na busca de uma identidade e na resistência, seja na fundação de Quilombos, seja no posicionamento social, ethos guerreiro e reacionário que surge não somente como resistência, mas como herança das origens africanas, resgate de valores trazidos do continente. ${ }^{31}$ E são esses movimentos sociais de deslocamento que se refletem no discurso em delocuções e elocuções que geram o discurso da negritude. Na relação ética apoiam-se os embates e instauram-se lutas por direitos e a busca por resgates de identidades.

É a noção de ethos, todavia, que vai dar corporeidade à cena de enunciação e ao discurso da negritude, por estar também relacionada ao campo das ideias. Há um hiperethos, incorporado nas imagens do negro construídas pelo enunciado e imagens de autor, que são o fiador do dizer, do dito e dos subentendidos.

Resgatando os enunciadores presentes nas diferentes cenas de enunciação, temos:

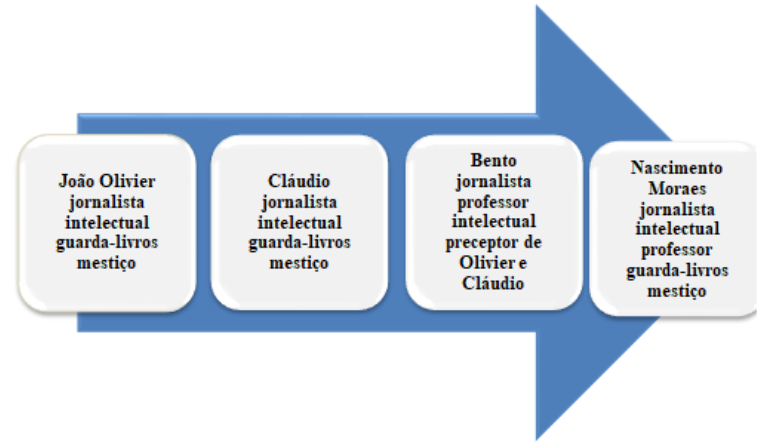

Figura 2 - Processo enunciativo I

31 O Maranhão é o estado que comporta a maior comunidade quilombola do país. 
João Olivier representa o enunciador que se faz ouvir por meio do discurso jornalístico. É a voz do oprimido, o ethos do intelectual engajado em causas sociais; Cláudio segue seus passos e se constitui no ethos refletido de seu pai (uma espécie de alter ego), uma extensão do ethos paterno. Bento era preceptor de ambos, o mais ufano de todos, um intelectual às antigas, sem muitos recursos financeiros, que luta pelos direitos da população, sobretudo, dos negros. Representam o ethos do negro politicamente engajado em busca de sua identidade coletiva.

Há um grande fiador para o discurso desses ethé, que se encontra na imagem de si, que o autor Nascimento Moraes constrói. Sua palavra na sociedade maranhense é de extremo valor, considerado pela minoria letrada, pela aristocracia e pela população. Constrói o ethos de um negro autônomo engajado nas causas políticas e sociais de sua cidade, estudioso e respeitado. Essa fiança é o primeiro elemento que cria o vínculo paratópico entre obra e criador para constituir-se num segundo movimento, o de paratopia testemunhal. Por conseguinte, quando se torna objeto de estudos da Historiografia, a paratopia é documental e, assim, o ethos contribui para a paratopia testemunho-documental.

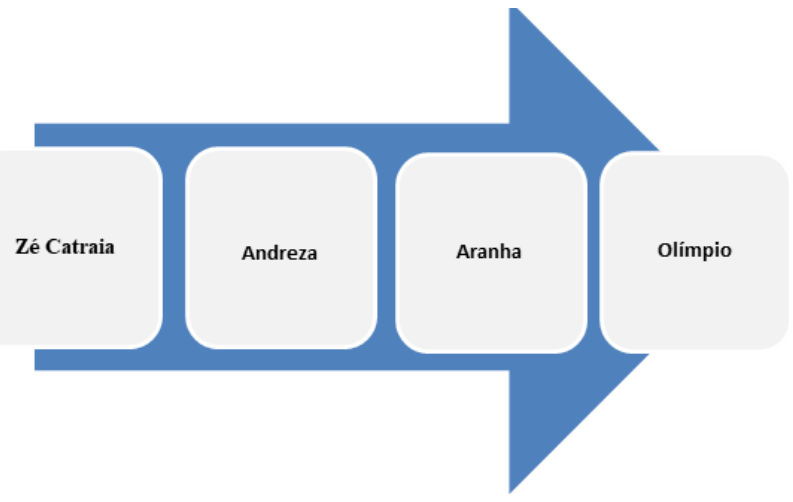

Figura 3 - Relações interlocutivas: processo enunciativo II 
Zé Catraia, Andreza, Aranha e Olímpio representam os ethé da resistência da negritude liberta. Zé Catraia representa o ethos da resistência marginalizada, que resiste em silêncio a tudo, observador da realidade social, defende seu povo, tal qual prevê a filosofia do Movimento Negro.

Andreza representa o ethos da resistência feminina. Apesar de marginalizada pela sociedade patriarcal, que a vê como mero objeto, ela se assume negra, aceita a liberdade e a marginalidade que o preconceito social impõe por sua cor e seu sexo, assume suas qualidades com dignidade e, apesar de violentada e abandonada, trabalha como lavadeira para educar o filho. A sensualidade naturalmente exposta em gestos e atitudes pode parecer para o olhar preconceituoso como objetificação feminina, contudo, há uma outra leitura necessária, assumir a sensualidade e mantê-la como resistência à aculturação é também traduzir o corpo em elemento discurso paratópico de resistência dentro do discurso literário, ou seja, a representação simbólica dessa sensualidade também corporifica uma possibilidade de resistência à imposições sociais.

Aranha e Olímpio representam o ethos da resistência identitária, a minoria que se enquadra socialmente sem perder sua história e sua identidade.

Em certa medida, esses ethé também são afiançados pela imagem do autor e por sua história de vida, uma vez que faz parte de sua história de vida ter sido educado por preceptores. Sua mãe contava-lhe histórias dos meandros das casas dos burgueses porque trabalhava como lavadeira, como Andreza, e seu pai era sapateiro, capoeirista e combatente como Aranha. A presença da capoeira, elemento frequente em cenas de enunciação com presença negra, não somente reitera um elemento cultural pertencente às condições sócio-históricas de produção, mas também reiteram a presença do corpo como manutenção da resistência. Assim, esse 
elemento que passa quase despercebido resiste ao perpetuar características culturais de força e luta.

No discurso literário, há um hiperethos, que impossibilita a apreensão de um ethos efetivo, aspecto já revisto inclusive por Maingueneau (2008c). Logo, esses ethé são discursivos, são verossimilhantes, e criam estereótipos ligados aos mundos éticos.

As práticas sociais geradas pelas relações de trabalho, pelo desenvolvimento comercial, político e cultural criam estereótipos responsáveis por racismo e preconceitos. Por meio deles, o negro é visto como serviçal nato, desordeiro, marginal, animalesco, desprovido de dotes intelectuais e excessivos sexuais. Estereótipos que se mantêm no inconsciente coletivo como em:

5. Coronel Patusco era o coronel Lousada, a quem Olivier pregou aquele apelido canalha, por causa de suas maneiras e hábitos na sociedade. O povo, porém, ferindo outro alvo, o alcunhara de - Alma Negra. (p. 30)

6. O Aranha não é mau homem, um perdido inteligente. É até de bons sentimentos, e a verdade é que chega a inspirar simpatia. (...) O homem bebe por desaforo! E quando chega ao mirante, não há quem o aguente! Briga por dez! A não ser isso, até é bom serviçal...(p. 87)

7. - É inteligente e altivo o rapaz! Tem feito progressos admiráveis nos estudos, apesar da perseguição que lhe movem despeitados e da má vontade que constantemente se manifesta contra ele, da parte dos professores, a princípio, e depois, por imitação, da parte dos colegas. (p. 87)

8 - A prevenção que há nesta terra contra todo rapaz que não descende das antigas famílias dos ominosos tempos! (p. 88)

9 - Na verdade, meu João, a mulher é um ente fraco, muito fraco...Ela temia, e por temer, constantemente, me repetia: - Meu sinhô me desgraçou! (p. 123)

Quadro III - Estereótipos e práticas sociais

Fonte: Vencidos e Degenerados (MORAES, 2000) 
O estereótipo do negro é associado a qualificações ruins [5]: o negro beberrão, pouco inteligente e de força física brutal [6] e [7], implícitas no discurso racista. A enunciação está marcada, inclusive, pelo eufemismo "prevenção" [8] para não associar diretamente suas limitações à cor da pele e à fragilidade feminina [9], usadas como desculpa para abusos sexuais. A situação comunicativa exprime a marginalização social e a atopia discursiva que acompanham esse enunciador. Há um estado de violência, um não-lugar que se apresenta no discurso e se reitera na cena.

Contra esses estereótipos preconceituosos e racistas, lutam os enunciadores envolvidos no discurso de negritude, por meio do qual, o enunciador não admite passivamente o darwinismo social, aceito por muitos cientistas da época.

\section{Considerações Finais}

As novas concepções de estudo do discurso e da linguagem, de um modo mais amplo, admitem que, no discurso, interagem o ethos do autor e o ethos do público a que se dirige o discurso, instituem-lhe "caráter" e "corporalidade". Essa intersubjetividade é o que Maingueneau (2001) chama de incorporação, aspecto fundamental para que as paratopias relacionadas ao criador existam, isto é, a paratopia testemunho-documental existe em Vencidos e Degenerados também porque o ethos do autor, a imagem do autor, o ethos do público (hiperethos literários) concorrem paralelamente como fiadores do discurso tópico. Pelas estratégias com que o ethos envolve o co-enunciador no processo de interação, as cenas de enunciação e cenografias criam vida, são validadas pela memória coletiva, incorporam uma voz popular e também podem ser apoiadas em cenas de fala. 
Não tomamos o ethos como foco principal do discurso, mas admitimos que características da linguagem e características socioculturais marcam sua presença no discurso para reafirmar ou negar, inclusive, caracteres identitários, que são apreendidos nas cenas de enunciação. Com efeito, tais categorias serviram nesse capítulo como suporte para primeiras reflexões sobre o papel do corpo como resistência paratópica participante das cenas de enunciação do discurso literário.

Tais inquietações são somente um primeiro passo para ampliação das categorias apresentadas em nosso trabalho de doutorado e um movimento ainda inicial no sentido de verificar e analisar a sensualidade, a embriaguez e a capoeira como resistência à realidade imposta pela sociedade escravocrata na confluência de poderes e embates.

\section{Referências}

ALTHUSSER, Louis. P. Aparelhos Ideológicos do Estado. $7^{\mathrm{a}} \mathrm{ed}$. Rio de Janeiro: Graal, 1998.

ARANTES, Marco A. Sartre e o Humanismo Racista Europeu: uma leitura sartriana de Frantz Fanon. Revista Interfaces: Sociologias, Porto Alegre, ano 13, no. 27, mai./ago. 2011, p. 382-409. Disponível em: http://www.scielo.br/pdf/soc/v13n27/a14v13n27. pdf. Acesso em: 30 mai. 2015.

BERNDT, Zilá. O que é negritude? São Paulo: Brasiliense, 1988.

CÉSAIRE, AIMÉ. Discurso sobre la negritud: negritud, etnicidad y culturas afroamericanas. Disponível em: file://C:/Users/Paulo\%20 Carreira/Downloads/Cesaire\%20Aim\%C3\%A9\%20-\%20Discurso\%20sobre\%20la\%20negritud.pdf. Acesso em: 20 de mai. 2015. FANON, Franz. Pele negra, máscaras brancas. Salvador: EDUFBA, 2008. 
FOULCAUT, Michel. O que é um autor? Trad. Antonio Fernando Cascais e Eduardo Cordeiro. Portugal: Passagens, 1992.

. Arqueologia do Saber. Rio de Janeiro: Forense, 2005a. . Em Defesa da Sociedade. São Paulo: Martins Fontes, 2005b.

. A ordem do discurso. São Paulo: Loyola, 2013.

HALL, Edward T. The silent lenguage. N.Y: Doubleday, 1959. . A dimensão oculta. Rio de Janeiro: Francisco Alves, 1977. (originalmente publicado em 1966)

HALL, Stuart. Da Diáspora: identidades e medicações culturais. Belo Horizonte: UFMG, 2013.

KNAP, Mark. L. La comunicación no verbal. España: Paidos Ibérica, 1982.

MAINGUENEAU, Dominique. Sémantique de la Polémique. Suiça: Edition L'Age D'Homme, 1983.

. Pragmática para o discurso literário. São Paulo: Martins Fontes, 1996.

. Novas tendências em análise do discurso. Campinas: Pontes, 1997.

. Análise de Textos de Comunicação. São Paulo: Cortez, 2001.

. Discurso literário. São Paulo: Contexto, 2006.

. A Análise do Discurso e Suas Fronteiras. Matraga, [S.1.], 2007, v. 14, n. 20, p. 13-37.

. Gênese dos discursos. São Paulo: Parábola, 2008a.

. Cenas da Enunciação. São Paulo: Parábola, 2008b.

. A Propósito do Ethos. In: MOTTA, R e SALGADO, L. Ethos Discursivo. São Paulo: Ed. Contexto, 2008c.

. Doze Conceitos em Análise do Discurso. Campinas: Parábola, 2010.

MUNANGA, Kabengele e GOMES, Nilma L. O Negro no Brasil de Hoje. São Paulo: Global, 2006. 
MUNANGA, Kabengele. Para entender o negro no Brasil de Hoje: História, Realidade, Problemas e Caminhos (livro do professor). São Paulo: Global/Ação Educativa, 2004.

- Origens africanas do Brasil Contemporâneo: Histórias, Línguas,Culturas e Civilizações. São Paulo: Global, 2007. . Negritude: usos e sentidos. São Paulo: Ática, 2009. . Negritude: usos e sentidos. Belo Horizonte: Autêntica, 2012.

PECHÊUX, Michel. Semântica e Discurso. Campinas: Ed. Da Unicamp, 1975.

Automatic Discourse Analysis. Amsterdam: Ed. Rodopi B.V, 1995.

SARTRE, Jean-Paul. Orfeo Negro. Disponível em: https://pt.scribd. com/doc/188012792/Jean-Paul-Sartre-Orfeo-Negro. Acesso em: 25 mai. 2015.

WOODWARD, Kathryn; HALL, Stuart e SILVA, Tomaz T. da (org). Identidade e Diferença: a perspectiva dos Estudos Culturais. São Paulo: Ed. Vozes, 2012. 